\title{
Effect of lupine (Lupinus termis) seeds or their water extract on alloxan diabetic rats
}

\author{
H. A. Hassan and M. M. El-Komy \\ Zoology Department, Faculty of Sciences, Mansoura University, Mansoura, Egypt.
}

\begin{abstract}
Diabetes mellitus represents a major public health problem. Much of the increased mortality and morbidity seen in diabetic patients is the result of various complications. Free radicals play an important role in the cause of complications of diabetes mellitus such as retinopathy, nephropathy, hypertension, arteriosclerosis and ischemic heart diseases. Many secondary plant metabolites have been shown to possess antioxidant activities, improving the effects of oxidative stress in diabetic patient. Thus the present study tries to evaluate the role of different preparations from Lupinus termis as a hypoglycemic agent. Alloxan diabetic rats were orally treated with either $5 \mathrm{ml} / \mathrm{Kg} \mathrm{b.wt/day} \mathrm{aqueous} \mathrm{lupine} \mathrm{seeds} \mathrm{extract} \mathrm{or} 20 \% \mathrm{w} / \mathrm{w}$ in diet edible boiled lupine seeds powder or $20 \%$ w/w dry lupine seeds powder for 30 days. The results recorded high levels of glucose, total cholesterol, triglycerides and LDL-cholesterol as well as low levels of total protein, HDL-cholesterol, liver glycogen and serum insulin in diabetic rats. Phospholipids content was increased in the serum but decreased in the liver and pancreas of diabetic rats. In addition, the results confirmed that the alloxan diabetic rats were subjected to oxidative stress as indicated by the extent of lipid peroxidation (high malondialdehide levels) present in the liver and pancreas and significantly alter activities of some scavenging enzymes (low glutathione reductase, glucose-6-phosphate dehydrogenase, superoxide dismutase and catalase). On the other hand, after administration of any one of the used preparations of lupine seeds, the diabetic rats revealed an improvement on various metabolic abnormalities as well as oxidative stress recorded with diabetes but the best improvement occurred in the animal group treated with dry seeds powder. These results give a good evidence for the amelioration effect of lupine against the alloxan diabetic effects.
\end{abstract}

Key words: Antidiabetic plants - seed extract - metabolic abnormalities - free radical - alloxan diabetic rats.

\section{Introduction}

Diabetes is one of the most common diseases especially in tropical area and the third world. Diabetes mellitus is a multifactorial disease, which is characterized by hyperglycemia and lipoprotein abnormalities (Scoppola et al., 2001). These trails are hypothesized to damage cell membranes which results in elevated production of reactive oxygen species (ROS)(Wolff et al., 1991). This generation of oxygen-free-radicals during cellular metabolism, and by certain environmental factors, including lifestyle, appears to play a critical role in the pathogenesis of diabetes (Hartnett et al., 2000). Hyperglycemia, the main symptom of diabetes, not only increases the production of ROS but also affects antioxidant reactions catalyzed by ROS scavenging enzymes (Uchimura et al., 1999). Diabetes mellitus has also been associated with an increased risk for developing premature atherosclerosis due to increase in triglycerides and low- density lipoprotein levels and decrease in high-density lipoprotein level (Bierman, 1992). All organisms possess antioxidant enzymes [superoxide dismutase (SOD), catalase (CAT) and glutathione peroxidase (GSHPx)] responsible for scavening ROS. A defect in ROS scavenging enzyme system has been reported in diabetes mellitus (Kesavulu et al., 2000 and Jung et al., 2004). 
If diabetes is not successfully treated and carefully controlled, many complications may be developed. Treatment of all forms of diabetes depends on normalizing the amount of insulin released from the $\beta$ cell or to adjust the requirements of tissue for nutrients to maintain metabolic homeostasis (Flier, 1992). This metabolic imbalance is responsible for the acute metabolic derangements of the chronic complications consequently, the major objective of all forms of treatments is the normalization of nutrients homeostasis and the attainment of this goal may prevent or delay the onset of complications (Mohen et al., 1991).

Nowadays, there is uprising awareness for going back to nature and getting away as much as possible from synthetic drugs. That is because many of the synthetic drugs have shown undesirable side effects, especially when used for long terms. Moreover, the hazardous side effects are even augmented when more than one synthetic drug are used simultaneously due to drug interaction (Sheela and Augusti, 1992). Many minor compounds of foods such as secondary metabolites, have been shown to alter biological processes which may reduce risk of chronic disease in humans. Recent studies showed that aqueous extracts of different antidiabetic plants enhanced insulin secretion and mimicked the effect of insulin on glucose metabolism in vitro (Gray and Flatt, 1998). Such dual pancreatic and extrapancreatic actions would prove to be an important advance on existing therapies used to treat and control diabetes, such as oral hypoglycemic drugs (which act either by enhancing insulin secretion or by improving the action of insulin or producing insulin resistance) (Gray and Flatt, 1997). These combined findings illustrate the enormous potential of plants for use as possible dietary adjuncts and the discovery of natural products for diabetes therapy (Gray et al., 2000).

lupine (Lupinus termis), an edible plant native to the North Africa, especially in Egypt, has been widely used in folk medicine for maintaining tolerance blood glucose levels (Riyad et al., 1988 and Zaahkouf, 2001). Shani et al. (1974) have shown that lupine seeds extract produced a mild and transient hypoglycemic effect in diabetic rats. This was somewhat contradictory to an earlier report by Helmi et al. (1969), where lupine seeds powder produced a pronounced hypoglycemic effect in both normal and diabetic rabbits. Moreover, the termis seed extracts used in treatment of chronic eczema of hands and act as anti-histaminic drug (Lemus et al., 1999). The authors also noted that lupinus termis extracts showed a blood pressure reduction in hypertensive rats. Studies are available with confecting results on the effects of termis on lowering the levels of cholesterol and triglycerides in diabetes (Rodriquez et al., 1998).

In view of these information, it was therefore of interest for us to evaluate the effect of different preparations of lupine seeds supplementation diets on the induction of experimental diabetes and its management as judged by blood glucose, lipid profile and oxidative stress in alloxan diabetic rats.

\section{Materials and Methods}

Plant material preparations:

Dried Lupine seeds were purchased from the local market. Water extract of lupine were obtained by boiling lupine seeds $(300 \mathrm{~g} / \mathrm{L})$ for one hour and the extract solution was stored in the refrigerator to avoid possible deterioration of active ingredients. The extract was given orally to rats daily by gastric intubations at a dose of $5 \mathrm{ml} / \mathrm{Kg}$ b.wt. at a concentration of $1500 \mathrm{mg} / \mathrm{Kg}$ (Zaahkouk, 2001). Two different diets supplemented with lupine seeds were also used for treatment, the first one was prepared by adding $20 \%$ (w/w in diet) edible boiled lupine seeds and the other one was prepared by adding $20 \%$ (w/w in diet) dry seeds powder (Riyad et al., 1988).

\section{Animals and treatment:}

Twenty-five male albino rats weighing $150-170 \mathrm{~g}$. were used in this work. Animals were kept under good ventilation and received a balanced diet and water ad libitum throughout the experiment. Diabetes was induced by interaperitoneal injection of a single dose 
of $120 \mathrm{mg}$ alloxan $/ \mathrm{Kg}$ b.wt., dissolved in acetate buffer ph 5.5, to overnight fasted rats (Othman, et al., 1989). Successful induction of diabetes was assessed 3 days after alloxan injection by performing glucose urine analysis Glukotest which was obtained from Bohringer, Mannheim Company, Germany.

The experimental animals were then divided into four groups, in addition to a control group that received a single interperitoneal (IP) injection of acetate buffer $\mathrm{pH}$ (5.5). The first one left as diabetic group. In the second group diabetic rats were treated daily with aqueous lupine seeds extract by gavage at a dosage of $5 \mathrm{ml} / \mathrm{Kg} \mathrm{b.wt}$. While, in the Third and fourth groups, the diabetic rats of each groups fed diets supplemented with $20 \%$ edible boiled lupine seeds powder or dry lupine seeds powder respectively. After 30 days from treatment, the rats were sacrificed and the blood was collected in non heparinized tubes and centrifuged at $4000 \mathrm{~g}$ for $10 \mathrm{~min}$ to remove the serum for biochemical determinations. Liver and pancreas specimens were surgically removed, immediately washed with ice cold saline and prepared for biochemical analysis.

\section{Biochemical analysis:}

The level of glucose and high density lipoprotein cholesterol (HDL-c) in the serum, in addition to the concentration of total lipids, total cholesterol, and triglycerides in serum, liver and pancrease were estimated using assay Kits (Purchased from Sigma Chemical Co, USA). Total protein (TP) was assayed by Biuret reaction according to Doumas (1975). The method of Baginiski et al. (1972) was adopted to determine the level of total phospholipids. Serum insulin levels was measured using immunoenzymatic assay Kits for the quantitative measurement of insulin in serum (Flier $e t$ al., 1979). Liver glycogen was estimated according to the technique of Van Handle (1965). Glucose-6-phosphate dehydrogenase (G6PD) activity was estimated depending on the method of Chan et al. (1965). Moreover, thiobarbituric acid reactive substances (TBARS) was determined as described by Esteribauer and Cheeseman (1990). The content of Glutathione (GSH) was estimated by the method of Prins and Loose (1969). Glutathione reductase (GSH-Rx) activity was determined by the method of Beutler (1975). The activity of superoxide dismutase (SOD) was assayed according to the method of Niskikimi et al. (1972). Catalase activity was detected as described by Aebi (1983).

\section{Statistical analysis:}

All results were expressed as mean \pm S.E of five animals. The obtained data were compared using Student t-test as described by Snedecor and Cochran (1982). The level of significance was expressed as significant at $\mathrm{P}<0.05$.

\section{Results}

The results of the present study as shown in tables 1 and 2 revealed that the injection of alloxan induced a significant increase in glucose level and significant decrease in liver glycogen content of the same animals. In addition, the present data showed that diabetic rats demonstrated significant increase in serum, liver and pancreas total lipids, total cholesterol, triglycerides and LDL-c concentrations. On contrary, serum HDL-c level and total protein content in the same examined tissues was significantly decreased after alloxan injection. In diabetic rats, phospholipid was significantly decrease in liver, while non significantly altered in both serum and pancreas. However, the obtained data regarding diabetes-induced changes in glucose and insulin levels in serum (table 1) as well as in liver glycogen content (table 2 ) showed occurrence of good treatrment by dry seeds powder (group 5) of lupine particularly glucose and insulin which were nearly returned to control values. Morever, the adminstration of lupine into diabetic rats showed progressive recovery in total protein conten as well as in the level of total lipids, total cholesterol, triglycerides, phospholipids, HDL-c and LDL-c in the examined tissues throughout the experimental duration. Whereas supplementated diets with $20 \%$ edible boiled 
lupine seeds powder (group 4) showed non significant change in the levels of the above mentioned serum, hepatic and pancreatic parameters comparing to diabetic rats group except the level of serum total lipids, where the decrease was significant as shown in Table (1\&2).

As shown in table 3 it is clear that the TBARS levels in diabetic rats were higher than in normal control group. However, diabetic rats displayed significant decrease in liver and pancreatic glutathione content as well as in the activities of GSH-Rs and SOD. Also, the data of the activity of G6PD and catalase enzymes recorded significant decrease in diabetic rats compared to control rats. Furthermore, the amelioration noted in the above mentioned paramneters after the treatment with water seeds extract or dry seeds powder while addition of edible boiled seeds lupine to the diet of diabetic rats (group 4) did not cause significant changes in the most oxidative stress as comared with diabetic rats (Table 3 ).

Table 1: Effect of lupine (Lupinus termis) on some serum biochemical parameters in diabetic rats

\begin{tabular}{|c|c|c|c|c|c|}
\hline $\begin{array}{c}\text { Animal } \\
\text { Groups } \\
\text { Parameters }\end{array}$ & $\begin{array}{l}\text { Control } \\
\text { group }\end{array}$ & $\begin{array}{l}\text { Diabetic } \\
\text { group }\end{array}$ & $\begin{array}{c}\text { Diabetic } \\
\text { +aqueous } \\
\text { seeds extract }\end{array}$ & $\begin{array}{l}\text { Diabetic } \\
\text { +edible } \\
\text { boiled seeds } \\
\text { powder }\end{array}$ & $\begin{array}{c}\text { Diabetic } \\
+ \text { dry seeds } \\
\text { powder }\end{array}$ \\
\hline $\begin{array}{c}\text { Glucose level } \\
(\mathrm{mg} / 100 \mathrm{ml})\end{array}$ & $112.5 \pm 2.4$ & $\begin{array}{c}398.4 \pm 3.4 \\
\mathrm{a}\end{array}$ & $\begin{array}{c}230.7 \pm 2.3 \\
a \& b\end{array}$ & $\begin{array}{c}388.1 \pm 6.6 \\
\mathrm{a}\end{array}$ & $\begin{array}{c}116.4 \pm 2.1 \\
b\end{array}$ \\
\hline $\begin{array}{l}\text { Insulin level } \\
(\mu \mathrm{U} / \mathrm{ml})\end{array}$ & $4.9 \pm 0.61$ & $\begin{array}{c}2.6 \pm 0.45 \\
a\end{array}$ & $\begin{array}{c}3.8 \pm 0.12 \\
b\end{array}$ & $\begin{array}{c}3.1 \pm 0.32 \\
\mathrm{a}\end{array}$ & $\begin{array}{c}4.6 \pm 0.25 \\
b\end{array}$ \\
\hline $\begin{array}{l}\text { Total protein } \\
(\mathrm{g} / 100 \mathrm{ml})\end{array}$ & $8.9 \pm 1.2$ & $\begin{array}{c}4.4 \pm 1.6 \\
\mathrm{a}\end{array}$ & $6.9 \pm 1.3$ & $\begin{array}{c}5.8 \pm 2.6 \\
a\end{array}$ & $\begin{array}{c}8.4 \pm 2.4 \\
b\end{array}$ \\
\hline $\begin{array}{l}\text { Total lipids } \\
(\mathrm{mg} / \mathrm{dl})\end{array}$ & $654.2 \pm 3.2$ & $\begin{array}{c}988.8 \pm 3.5 \\
\mathrm{a}\end{array}$ & $\begin{array}{c}811.4 \pm 4.2 \\
\mathrm{a} \& \mathrm{~b}\end{array}$ & $961.7 \pm 2.7 \mathrm{a} \& \mathrm{~b}$ & $\begin{array}{c}724.3 \pm 3.7 \mathrm{a} \\
\& \mathrm{~b}\end{array}$ \\
\hline $\begin{array}{l}\text { Total cholesterol } \\
(\mathrm{mg} / \mathrm{dl})\end{array}$ & $198.4 \pm 3.2$ & $\begin{array}{c}354.3 \pm 3.5 \\
\mathrm{a}\end{array}$ & $\begin{array}{c}280.4 \pm 2.3 \\
a \& b\end{array}$ & $\begin{array}{c}334.1 \pm 6.3 \\
\mathrm{a}\end{array}$ & $\begin{array}{c}203.6 \pm 4.1 \\
b\end{array}$ \\
\hline $\begin{array}{l}\text { Triglycerides } \\
(\mathrm{mg} / \mathrm{dl})\end{array}$ & $87.5 \pm 2.1$ & $\begin{array}{c}140.4 \pm 3.2 \\
\mathrm{a}\end{array}$ & $\begin{array}{c}103.6 \pm 3.6 \\
a \& b\end{array}$ & $\begin{array}{c}136.2 \pm 4.5 \\
\mathrm{a}\end{array}$ & $\begin{array}{c}91.2 \pm 2.5 \\
b\end{array}$ \\
\hline $\begin{array}{c}\text { Phospholipids } \\
(\mu \mathrm{mol} / \mathrm{min} / 100 \mathrm{ml})\end{array}$ & $6.4 \pm 2.3$ & $7.9 \pm 0.41$ & $6.02 \pm 1.5$ & $7.5 \pm 0.85$ & $\begin{array}{c}8.5 \pm 0.46 \\
b\end{array}$ \\
\hline $\begin{array}{l}\text { HDL-cholesterol } \\
(\mathrm{mg} / \mathrm{dl})\end{array}$ & $41.2 \pm 2.4$ & $\begin{array}{c}33.1 \pm 1.3 \\
\mathrm{a}\end{array}$ & $\begin{array}{c}38.2 \pm 1.2 \\
b\end{array}$ & $\begin{array}{c}36.4 \pm 1.7 \\
\mathrm{a}\end{array}$ & $\begin{array}{c}44.2 \pm 1.5 \\
b\end{array}$ \\
\hline $\begin{array}{l}\text { LDL-cholesterol } \\
(\mathrm{mg} / \mathrm{dl})\end{array}$ & $139.4 \pm 2.6$ & $\begin{array}{c}293.1 \pm 8.1 \\
\mathrm{a}\end{array}$ & $\begin{array}{c}221.5 \pm 1.4 \\
a \& b\end{array}$ & $\begin{array}{c}270.5 \pm 9.6 \\
\mathrm{a}\end{array}$ & $\begin{array}{c}141.2 \pm 2.8 \\
\mathrm{~b}\end{array}$ \\
\hline
\end{tabular}

Values are presented as means \pm SE. $(n=5)$.

$\mathrm{a} \rightarrow \mathrm{P}<0.05$ versus control group.

$\mathrm{b} \rightarrow \mathrm{P}<0.05$ versus diabetic group. 
Table 2: Effect of lupine (Lupinus termis) on some hepatic and pancreatic biochemical parameters in diabetic rats.

\begin{tabular}{|c|c|c|c|c|c|c|}
\hline & $\begin{array}{c}\text { Animal } \\
\text { Groups } \\
\text { Parameters }\end{array}$ & $\begin{array}{l}\text { Control } \\
\text { group }\end{array}$ & $\begin{array}{l}\text { Diabetic } \\
\text { group }\end{array}$ & $\begin{array}{c}\text { Diabetic } \\
\text { +aqueous } \\
\text { seeds extract }\end{array}$ & $\begin{array}{c}\text { Diabetic } \\
\text { +edible boiled } \\
\text { seeds powder }\end{array}$ & $\begin{array}{l}\text { Diabetic }+ \text { dry } \\
\text { seeds powder }\end{array}$ \\
\hline \multirow{6}{*}{$\sum_{\overline{0}}^{\bar{D}}$} & $\begin{array}{l}\text { Glycogen content } \\
\text { (mg/g wet tissue) }\end{array}$ & $8.8 \pm 1.3$ & $\begin{array}{c}4.3 \pm 1.4 \\
\mathrm{a}\end{array}$ & $6.7 \pm 1.2$ & $\begin{array}{c}4.7 \pm 1.4 \\
\mathrm{a}\end{array}$ & $7.5 \pm 1.7$ \\
\hline & $\begin{array}{l}\text { Total protein } \\
\text { (g/100g wet } \\
\text { tissue) }\end{array}$ & $18.6 \pm 2.6$ & $\begin{array}{c}11.6 \pm 2.2 \\
\mathrm{a}\end{array}$ & $17.5 \pm 3.6$ & $13.8 \pm 4.1$ & $17.8 \pm 2.8$ \\
\hline & $\begin{array}{l}\text { Total lipids (mg/g } \\
\text { wet tissue) }\end{array}$ & $53.1 \pm 0.54$ & $\begin{array}{c}74.3 \pm 0.81 \\
\mathrm{a}\end{array}$ & $\begin{array}{c}59.2 \pm 0.74 \\
a \& b\end{array}$ & $\begin{array}{c}68.1 \pm 0.97 \\
\mathrm{a}\end{array}$ & $\begin{array}{c}51.03 \pm 0.54 \\
\mathrm{a} \& \mathrm{~b}\end{array}$ \\
\hline & $\begin{array}{c}\text { Total cholesterol } \\
\text { (mg/100g wet } \\
\text { tissue })\end{array}$ & $135.2 \pm 5.6$ & $\begin{array}{c}174.5 \pm 4.1 \\
\mathrm{a}\end{array}$ & $\begin{array}{c}142.7 \pm 3.8 \\
b\end{array}$ & $\begin{array}{c}169.7 \pm 4.1 \\
\mathrm{a}\end{array}$ & $\begin{array}{c}132.2 \pm 3.6 \\
b\end{array}$ \\
\hline & $\begin{array}{c}\text { Triglycerides } \\
\text { (mg/g wet tissue) }\end{array}$ & $32.4 \pm 2.5$ & $\begin{array}{c}54.2 \pm 1.3 \\
\mathrm{a} \\
\end{array}$ & $\begin{array}{c}35.7 \pm 1.8 \\
b\end{array}$ & $\begin{array}{c}49.9 \pm 2.4 \\
\mathrm{a}\end{array}$ & $\begin{array}{c}34.6 \pm 2.9 \\
b\end{array}$ \\
\hline & $\begin{array}{c}\text { Phospholipids } \\
\text { ( } \mu \mathrm{mol} / \mathrm{min} / \mathrm{g} \text { dry } \\
\text { tissue })\end{array}$ & $48.8 \pm 1.6$ & $\begin{array}{c}32.9 \pm 1.6 \\
\mathrm{a}\end{array}$ & $\begin{array}{c}42.1 \pm 2.9 \\
\mathrm{a} \& \mathrm{~b}\end{array}$ & $\begin{array}{c}34.5 \pm 2.6 \\
\mathrm{a}\end{array}$ & $\begin{array}{c}47.4 \pm 3.6 \\
b\end{array}$ \\
\hline \multirow{5}{*}{ 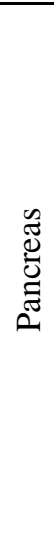 } & $\begin{array}{l}\text { Total protein } \\
\text { (g/100g wet } \\
\text { tissue) }\end{array}$ & $14.9 \pm 1.2$ & $\begin{array}{c}11.8 \pm 0.87 \\
\mathrm{a}\end{array}$ & $12.8 \pm 1.3$ & $\begin{array}{c}11.6 \pm 0.96 \\
\mathrm{a}\end{array}$ & $13.8 \pm 1.4$ \\
\hline & $\begin{array}{c}\text { Total lipids }(\mathrm{mg} / \mathrm{g} \\
\text { wet tissue) }\end{array}$ & $44.2 \pm 3.5$ & $54.2 \pm 4.8$ & $43.2 \pm 6.5$ & $51.3 \pm 5.2$ & $\begin{array}{c}39.3 \pm 4.1 \\
b\end{array}$ \\
\hline & $\begin{array}{c}\text { Total cholesterol } \\
\text { (mg/100g wet } \\
\text { tissue })\end{array}$ & $19.5 \pm 3.06$ & $\begin{array}{c}30.2 \pm 2.4 \\
\mathrm{a}\end{array}$ & $23.1 \pm 3.1$ & $28.5 \pm 5.2$ & $\begin{array}{c}19.9 \pm 4.6 \\
b\end{array}$ \\
\hline & $\begin{array}{c}\text { Triglycerides } \\
\text { (mg/g wet tissue) }\end{array}$ & $23.8 \pm 2.6$ & $\begin{array}{c}38.7 \pm 1.7 \\
\mathrm{a} \\
\end{array}$ & $\begin{array}{c}30.6 \pm 1.2 \\
\mathrm{a} \& \mathrm{~b}\end{array}$ & $\begin{array}{c}36.1 \pm 2.8 \\
\mathrm{a}\end{array}$ & $\begin{array}{c}31.5 \pm 2.5 \\
\mathrm{a} \& \mathrm{~b}\end{array}$ \\
\hline & $\begin{array}{c}\text { Phospholipids } \\
(\mu \mathrm{mol} / \mathrm{min} / \mathrm{g} \text { dry } \\
\text { tissue })\end{array}$ & $34.7 \pm 1.3$ & $30.4 \pm 2.8$ & $35.4 \pm 2.7$ & $31.2 \pm 4.1$ & $\begin{array}{c}36.6 \pm 1.5 \\
b\end{array}$ \\
\hline
\end{tabular}

Values are presented as means \pm SE. $(\mathrm{n}=5)$.

$\mathrm{a} \rightarrow \mathrm{P}<0.05$ versus control group.

$\mathrm{b} \rightarrow \mathrm{P}<0.05$ versus diabetic group. 
Table 3: Effect of lupine (Lupinus termis) on some hepatic and pancreatic antioxidant parameters in diabetic rats.

\begin{tabular}{|c|c|c|c|c|c|c|}
\hline & $\begin{array}{c}\text { Animal } \\
\text { Groups } \\
\text { Parameters }\end{array}$ & $\begin{array}{l}\text { Control } \\
\text { group }\end{array}$ & $\begin{array}{l}\text { Diabetic } \\
\text { group }\end{array}$ & $\begin{array}{c}\text { Diabetic } \\
\text { +aqueous } \\
\text { seeds extract }\end{array}$ & $\begin{array}{l}\text { Diabetic } \\
\text { +edible } \\
\text { boiled seeds } \\
\text { powder }\end{array}$ & $\begin{array}{c}\text { Diabetic } \\
\text { +dry seeds } \\
\text { powder }\end{array}$ \\
\hline \multirow{6}{*}{ 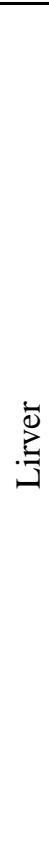 } & $\begin{array}{c}\text { TBARS } \\
\text { (n.mol/g wet } \\
\text { tissue) }\end{array}$ & $45.4 \pm 2.3$ & $\begin{array}{c}67.5 \pm 3.5 \\
a\end{array}$ & $\begin{array}{c}49.2 \pm 2.4 \\
b\end{array}$ & $\begin{array}{c}65.4 \pm 3.6 \\
a\end{array}$ & $\begin{array}{c}46.6 \pm 2.7 \\
b\end{array}$ \\
\hline & $\begin{array}{c}\text { GSH } \\
\text { (mg/g wet } \\
\text { tissue) }\end{array}$ & $7.2 \pm 0.14$ & $\begin{array}{c}3.5 \pm 0.12 \\
\mathrm{a}\end{array}$ & $\begin{array}{c}5.5 \pm 0.08 \\
\mathrm{a} \& \mathrm{~b}\end{array}$ & $\begin{array}{c}3.7 \pm 0.11 \\
\mathrm{a}\end{array}$ & $\begin{array}{c}5.7 \pm 0.16 \\
a \& b\end{array}$ \\
\hline & $\begin{array}{l}\text { GSH-Rx } \\
\text { (U//g wet } \\
\text { tissue) }\end{array}$ & $68.7 \pm 1.04$ & $\begin{array}{c}50.4 \pm 0.58 \\
\mathrm{a}\end{array}$ & $\begin{array}{c}55.4 \pm 0.83 \\
\mathrm{a} \& \mathrm{~b}\end{array}$ & $\begin{array}{c}51.4 \pm 0.48 \\
a\end{array}$ & $\begin{array}{c}59.4 \pm 0.36 \\
\mathrm{a} \& b\end{array}$ \\
\hline & $\begin{array}{c}\text { G6PD } \\
\text { (U/g wet tissue) }\end{array}$ & $3.8 \pm 0.10$ & $\begin{array}{c}2.03 \pm 0.09 \\
\mathrm{a}\end{array}$ & $\begin{array}{c}3.1 \pm 0.12 \\
\mathrm{a} \& \mathrm{~b}\end{array}$ & $\begin{array}{c}2.2 \pm 0.08 \\
\mathrm{a}\end{array}$ & $\begin{array}{c}3.6 \pm 0.09 \\
b\end{array}$ \\
\hline & $\begin{array}{l}\text { SOD (U/g wet } \\
\text { tissue) }\end{array}$ & $33.6 \pm 1.4$ & $\begin{array}{c}27.4 \pm 1.5 \\
a\end{array}$ & $30.5 \pm 1.2$ & $\begin{array}{c}28.2 \pm 1.4 \\
\mathrm{a}\end{array}$ & $\begin{array}{c}32.5 \pm 1.5 \\
b\end{array}$ \\
\hline & $\begin{array}{c}\text { Catalase } \\
\text { (KU/sec/g wet } \\
\text { tissue) }\end{array}$ & $0.39 \pm 0.004$ & $\begin{array}{c}0.20 \pm 0.005 \\
\mathrm{a}\end{array}$ & $\begin{array}{c}0.25 \pm 0.006 \\
\mathrm{a} \& \mathrm{~b}\end{array}$ & $\begin{array}{c}0.21 \pm 0.004 \\
\mathrm{a}\end{array}$ & $\begin{array}{c}0.32 \pm 0.004 \\
\mathrm{a} \& \mathrm{~b}\end{array}$ \\
\hline \multirow{6}{*}{ 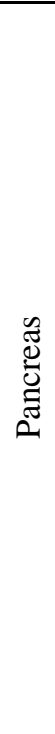 } & $\begin{array}{c}\text { TBARS } \\
\text { (n.mol/g wet } \\
\text { tissue) }\end{array}$ & $21.5 \pm 1.5$ & $\begin{array}{c}34.1 \pm 2.8 \\
\mathrm{a}\end{array}$ & $\begin{array}{c}26.5 \pm 2.6 \\
b\end{array}$ & $\begin{array}{c}31.2 \pm 1.2 \\
\mathrm{a}\end{array}$ & $\begin{array}{c}24.1 \pm 2.1 \\
b\end{array}$ \\
\hline & $\begin{array}{c}\text { GSH } \\
\text { (mg/g wet } \\
\text { tissue) } \\
\end{array}$ & $3.4 \pm 0.14$ & $\begin{array}{c}1.5 \pm 0.11 \\
\mathrm{a}\end{array}$ & $\begin{array}{c}2.4 \pm 0 . .15 \\
\mathrm{a} \& \mathrm{~b}\end{array}$ & $\begin{array}{c}1.8 \pm 0.17 \\
\mathrm{a}\end{array}$ & $\begin{array}{c}2.9 \pm 0.19 \\
a \& b\end{array}$ \\
\hline & $\begin{array}{c}\text { GSH-Rx } \\
\text { (U/g wet tissue } \\
\text { ) }\end{array}$ & $18.8 \pm 0.12$ & $\begin{array}{c}13.2 \pm 0.15 \\
\mathrm{a}\end{array}$ & $\begin{array}{c}17.9 \pm 0.14 \\
\mathrm{a} \& \mathrm{~b}\end{array}$ & $\begin{array}{c}13.4 \pm 0.19 \\
\mathrm{a}\end{array}$ & $\begin{array}{c}18.5 \pm 0.18 \\
b\end{array}$ \\
\hline & $\begin{array}{c}\text { G6PD } \\
\text { (U/g wet tissue) }\end{array}$ & $1.3 \pm 0.003$ & $\begin{array}{c}0.89 \pm 0.001 \\
\mathrm{a}\end{array}$ & $\begin{array}{c}1.2 \pm 0.002 \\
\mathrm{a} \& \mathrm{~b}\end{array}$ & $\begin{array}{c}0.90 \pm 0.006 \\
\mathrm{a}\end{array}$ & $\begin{array}{c}1.29 \pm 0.005 \\
b\end{array}$ \\
\hline & $\begin{array}{c}\text { SOD }(\mathrm{U} / \mathrm{g} \text { wet } \\
\text { tissue) }\end{array}$ & $6.4 \pm 0.09$ & $\begin{array}{c}4.8 \pm 0.11 \\
\mathrm{a} \\
\end{array}$ & $\begin{array}{c}5.7 \pm 0.05 \\
\mathrm{a} \& \mathrm{~b}\end{array}$ & $\begin{array}{c}4.9 \pm 0.13 \\
\mathrm{a} \\
\end{array}$ & $\begin{array}{c}6.2 \pm 0.12 \\
b\end{array}$ \\
\hline & $\begin{array}{c}\text { Catalase } \\
\text { (KU/sec/g wet } \\
\text { tissue) }\end{array}$ & $0.18 \pm 0.02$ & $\begin{array}{c}0.12 \pm 0.004 \\
\mathrm{a}\end{array}$ & $\begin{array}{c}0.16 \pm 0.003 \\
b\end{array}$ & $\begin{array}{c}0.13 \pm 0.01 \\
\mathrm{a}\end{array}$ & $\begin{array}{c}0.17 \pm .0 .01 \\
\mathrm{~b}\end{array}$ \\
\hline
\end{tabular}

Values are presented as means \pm SE. $(n=5)$.

$\mathrm{a} \rightarrow \mathrm{P}<0.05$ versus control group.

$\mathrm{b} \rightarrow \mathrm{P}<0.05$ versus diabetic gro 


\section{Discussion}

The present data demonstrated that, alloxan-induced diabetic rats showed a marked disturbance as severe hyperglycemia and hypoinsulinemia. Hyperglycemia can be considered as a direct reflex to the marked hypoinsulinemia caused by the selective destructive cytotoxic effect of alloxan on the $\beta$-cells of the pancreas (Bolaffi et al., 1986). The biochemical basis of diabetes-induced insulin resistance could involve changes in glucose transporter numbers (Lillioja et al., 1988) or in insulin-induced activation of glycogen synthesis, which reflect primarly depressed glycogen synthesis ((Margolis et al., 1985 and Ortmeyer et al., 1994). This could provide explanation for the decreased ability of the liver to accumulate glycogen in the present study. In association with these reportedly diabetes induced changes in carbohydrate metabolism, various studies have demonstrated a general elevation in almost plasma lipid fractions that often coexists with hyperglycemia (Orchard, 1990 and Betteridge, 1994). Apparently, the most comonly elevated plasma lipids in diabetes is the triglycerides, total cholesterol and LDL-c levels. In our study, alloxandiabetic rats exhibited marked hyperlipidemia, hypertriglyceridemia and hypercholesterolemia in serum, liver and pancreas, a result which agree with that of Jaiprakash et al. (1993) and Ginsberg (1996). Because insulin is known to supress VLDL secretion, the lack of this suppression by deficient insulin secretion in diabetes may lead to hypertriglyceridemia, which possibly can mediate the mechanism by which diabetes causes hyperlipidemia (Saudek and Eder, 1979). The detected increase in cholesterol may origenate from the increase in cholesterol biosynthesis in various tissues and its migration to the blood circulation (Zaahkouk, 2001). In other words, the reduction in the rate of cholesterol removal from circulation appears responsible for hypercholesterolemia recognized in diabetic states (Ebara, 1994). Diabetic dyslipidemia is due mainly to decreased removal of triglycerides into the fat depots, also the increase in serum concentration of very low density lipoprotein (VLDL) and low density lipoprotein (LDL) may be due to overproduction of VLDL by the liver or decreased removal of VLDL and LDL from the circulation (Tsutsumi et al., 1995).

Furthermore, in the present work, diabetic rats showed a significant decrease in serum liver and pancreas total protein content. Mortimore and Mondon (1970) found that lack of insulin effects on synthesis of hepatic protein. Therefore, the major effect of insulin on hepatic protein metabolism of proteolysis (Nair et al., 1983) and thus it appears that the decreased protein contents observed in the present diabetic study was a result of increased protein breakdown rather than decreased protein synthesis (Devlin et al., 1994).

The present data, on the other hand, revealed that the different preparations from lupine seeds intake to alloxan diabetic rats suppressed the various metabolic disturbances associated with diabetes. This is indicated by an improvement of glucose and insulin levels, concomitantly with tendency of hepatic glycogen content to nearly control value, indicating stimulated glucose utilization. Furthermore, lipid fractions were found to be lowered near to normal values. At the same time, no lipid deposition occurred in both liver and pancreas tissues, indicating that the serum lipid lowering effect of lupine was not mediated by a transport of lipids from serum to the tissues. Along with this, amelioration in the level of total proteins were observed in the serum and in both pancreas and liver following lupine treatment.

The present results run in agreement with the previous studies of Harazti and Vetter (1983) and Zahran (2004). These observed metabolic improvements could contribute to the hypoglycemic effect of Lupinus termis that may be due to its alkaloidal contents of sparteine and lupinine and /or its high manganese content, (Abdel-Kader, 1986 and Al-zaid, 
1987). Manganese chloride has been shown to exert a hypoglycemic action in independent diabetic mellitius (IDDM) patients and manganese is now recognized as necsssary co-factor for ATP phosphorylation of $\beta$-subunit of the insulin receptor (Reddy and King, 1987). Moreover, the treatment with manganese salt resulted in a net increase in acute insulin response and the rate fg glucose disappearance after glucose loading (White and Campell, 1993). Also the effect of lupine seeds in lowering blood glucose level in alloxan diabetic rats may be due to the positive action of these plants on the impaired glucoreceptor mechanism in diabetes and indirectly in large part perhaps dependent on insulin release from the pancrease (Kimura et al., 1981).

There are several explanations for the hypoglycemic effect of lupinus termis. Helmi et al. (1969) suggeseted that the lupinus termis has a potency effect equal to those of oral hypoglycemic drugs, like tolbutamide or acetohexamide. Moreover, Youness et al. (1985) concluded that, this plant can used as a safe and natural mean to lower blood glucose level. Meanwhile, Abdel-Aal et al. (1993) found that Lupinus seeds produced a definite hypoglycemic effect in normal and alloxan-diabetic rats. The authers attributed this results to the considerable improvement in the histologic picture of the islets of Langerhans of the pancreas which was noticed by lupine seeds administration. The islets increased in number and size compared to those in the alloxan-diabetic rats. Also, Bwititi et al. (2002) observed that the plant has possibly a pancreatic $\beta$-cell stimulating action (as an insulinreleasing natural product). This view might run in accordance with earlier study of Collip (1923) who suggested that in the plant kingdom there is a hormone analogus to insulin, which is known as glucokinin. In addition to, the anti-diabetic activity of the Lupinus termis may be due to the presence of an active ingredient such as lupanine where lupanine is the main alkaloide which cause hypoglycemic action (Ajabnoor and Tilmisany, 1988). In this study, both water seeds extract or dry seeds lupine powder significantly reduced the triglyceride, total cholesterol, phospholipids and LDL-c levels as well as increased HDL-c level in treated diabetic rats when compared to untreated diabetic rats. These reduction could be benificial in preventing diabetic complications as well as improving metabolism in diabetics (Cho et al., 2002). This decrease in the lipid fractions may be due to utilization of circulating free fatty acid by the liver and/or its fairly high contents of fiber and plant protein (Gabrial and Morcos, 1976). The present suggestion is based on the findings of Trowell (1972) who found that dietary fiber decreases the reabsorption of bile salts, increases fecel excretion, reduced hyperlipidemia and may exhibit a hypocholesterolemic effect in rats. Also, treatment with aqueous plant extract or dry seeds powder ameliorated the disturbance of protein in serum, liver and pancreas of diabetic rats. These findings are in accordance with Zaahkouk (2001) who recorded remarkable increase in serum total protein and globulin in diabetic rats treated with aqueous lupine and fenugreek extracts. This increas in protein content may be due to high protein content of the lupinus termis (Gabrial and Morcos, 1976).

Furthermore, impaired glucose metabolism leads to oxidative stress (Ceriello et al., 1992) and protein glycation products free radicals (Wolff et al., 1991). Therefore, the presently noted decreases in antioxidant enzymes activity in control diabetic rats when compared to diabetic rats treated with the aqueous seeds extract or seeds powder from lupinus termis could at least in part result from inactivation of the enzymes by $\mathrm{H}_{2} \mathrm{O}_{2}$ or by glycation, which are known to occure during diabetes (Sozmen et al., 2001). In search of a second factor conditioning such as oxygen radicals accumulation we have measured the level of the principal non-enzymatic antioxidant GSH. The detected decreased in GSH content in this study in concomitant with the lowered GSHRx activity observed in diabetic rats. An association between the impairment in GSHRx activity and GSH depletion is suggested by the observation of Murakami et al. (1989). Moreover, the present finding of decreased G6PD 
activity, may relate in part to decreased GSH level observed in this study. A view which supported by Montgomery et al. (1980) who showed that the reduced G6PD activity may be in part involved in the mechanism of GSH depletion in diabetes. Lipid peroxidation were also evaluated by measuring hepatic and pancreatic levels of TBARS. In agreement with other studies (Aydin et al., 2001 and Cho et al., 2002), we observed a significant increase in TBARS levels. This increase may be attributed to the increased peroxidative destruction of cellular membrane phospholipids. Moreover, the change in phospholipid fatty acids composition in the cellular membranes in diabetes may lead to increased lipid peroxidation, leading to disturbance of both membrane structure and function (Weber, 1994). The results from the present study showed that diabetes decreases phospholipids content in both pancreas and liver seems to support this suggestion.

On the other hand, our results have demonstrated the efficacy of some preperations of lupine seeds to prevent the progression of cellular lipid peroxidation, as indicated by the decreased TBARS level in both liver and pancreas tissues, along with restoring the normal phospholipids content in the examined tissues. The marked improvement in oxidative stress may be attributed to the antioxidant defense function of traditional antidiabetic plants as shown by increased reduced glutathione content as well as glutathione reductase, glucose 6-phosphate dehdrogenase, superoxide dismutase and catalase enzymes activity (Ugochukwu, et al., 2003). Supporting this suggestion, it has been mentioned that termis has a potant to act as free radical scavenger, hypolipidemic and hypoglycemic agents by the effect of lupanine and sparteine. The latters have the ability to bind or chelate the divalent cation which led to decrease in the oxidative stress and oxidation damage in tissue (Helmi et al., 1969 and Shani et al., 1974).

From the present investigation, it could be concluded that diabetes leads to several complications such as hyperglycemia, hyperlipidemia, disturbance in the lipid peroxidation and elevation in the free radicals. On the other hand, treatment of diabetic rats with lupinus termis exerts antidiabetic action against alloxan diabetic effects through modulation of the various metabolic disturbances associated with diabetes, in addition to the improvement in the defense mechanisms in examined tissues. Finally, it is obvious that the used of dry seeds powder of lupinus as hypoglycemic agent mean to lessen successfully the complications of diabetes better than seeds extract or boiled seeds of lupine, suggesting the possibility that the addition of antidiabetic plants to the treatment protocols used for diabetic patients may improve diabetic therapy.

\section{References}

1. Abdel-Aal, W. E.; Abel-Nabi, I.M.; Hanaa, R.A. and Mahdy, K.A. (1993): Biochemical and histopathological changes in normal and alloxan diabetic rats after lupine seeds adminstration. J. Egypt. Ger. Soc. Zool., 10(A): 251-267.

2. Abdel-Kader, M.K. (1986): Hypoglycemic effect of Ambrosia maritima on diabetic rabbits. M.Sc. Thesis, Fac. Sci Assuit Univ.

3. Aebi, H.E. (1983): Catalase in: Method of EnzymaticAanalysis vol. 3, Berlin ed H.V. Bergmeyer: Verlag Chemie. PP. 273-286.

4. Ajabnoor, M. A. and Tilmisany, A.K. (1988): Effect of Trigonella foenum graecumon on blood glucose levels in normal and alloxan-diabetic mice. J. Ethnopharmacol., 22: 45-49.

5. Al-Zaid, M.M. (1987): On the hypoglycemic action of Eugenia jambolana, Lupinus termis and Peganum harmala on non-diabetic rats. M.Sc. Thesis, Faculty of Science, Kuwait University.

6. Aydin, A.; Orhan, H.; Sayal, A.; Ozata, M.; Sahin, G. and Isimer, A. (2001): Oxidative stress and nitric oxide related parameters in type II diabetes mellius:Effect of glycemic control. Clin. Biochem., 34: 65-70.

7. Baginiski, E. B.; Epsteine, E. and Zak, B. (1972): Determination of phospholipids in plasma. Ann. Clin. Lab. Sci., 2 : 255-260.

8. Betteridge, D. J. (1994): Diabetic dyslipidemia. Am. J. Med. (Suppl. 6A) 96: 25S-31S.

9. Beutler, E. (1975): Red Cell Metabolism a Manual of Biochemical Methods. $2^{\text {nd }}$ 
edition Publ. Grune and stration, New York, pp. 69-70.

10. Bierman, E.L. (1992): Atherogenesis in diabetes. Arterioscler. Thromb., 12: 647656.

11. Bolaffi, J.L.; Nowlain, R. E.; Gruz, L. and Grodsky, G.M. (1986): Progressive damage of cultured pancreatic islets after single early exposure to streptozotocin. Diabetes, 35: 1027-1033.

12. Bwititi, P.; Musabayane, C. and Nhachi, C. F. (2000): Effects of Opuntid megacantha on blood glucose and kidney function in STZ diabetic rats. Ethano. Pharmacol., 69(3): 247-252.

13. Ceriello, A.; Quatraro, A. and Giugliano, D. (1992): New insights on non-enzymatic glycosylation may lead to therapeutic approaches for the prevention of the diabetic complications. Diabet. Med., 9: 297-299.

14. Chan, T. K.; Todd, D. and Wong, C. C. (1965): An examination of the role of trace metals and some other parameters on the phagocytic process. J. Lab. Clin. Med., 66: 936-940.

15. Cho, S-Y.; Park, J-Y.; Park, E.M.; Choi, M. S.; Lee, M-Y.; Jeon, S.M.; Jang, M-K.; Kim, M. J. and Park, Y-B. (2002): Alternation of hepatic antioxidant enzyme activities and lipid profil in streptozotocin-induced diabetic rats by supplementation of dandelion water extract. Clin. Chem. Acta., 317: 109-117.

16. Collip, J. B. (1923): Glucokinin, new hormone present in plant tissue. J. Biol. Chem., 56: 513-543.

17. Devlin, J. T.; Scrimgeour, A. ; Brodsky, I. and Fulier, S. (1994): Decreased protein catabolism after exercise in subjects with IDDM. Diabetologia, 37: 358-364.

18. Doumas, B. T. (1975): Colorimetric determination of total protein based on the Biuret method., Clin. Chem. 21: 11591166.

19. Ebara, H. T.; Mamo, J.C.L.; Sakamaki, R.; Furukawa, S.; Nagano, S. and Takahashi, T. (1994): Hyperlipidemia in streptozotocin-diabetic hamasters as a model for human insulin deficient diabetes: Comparison to streptozotocin-diabetic rats. Met. Clin. Exp., 43 : 299-305.

20. Esteribauer, H. and Cheeseman, K. (1990): Determination of aldehdic lipid peroxidation products: Malonaldehyde and 4- hydroxyonenal. Enzymol.; 186: 407421.

21. Flier, J.S.; Kahn, C. R. and Roth, J. (1979): Receptors, antireceptor antibodies and mechanisms of insulin resistance. N. Engl. J. Med., 300: 413-418.

22. Flier, J.S. (1992): Syndromes of insulin resistance from patient to gene and back again. Diabetes, 41: 1207-1219.

23. Gabrial, G.N. and Morcos, S.R. (1976): The use of Lupinus termis L. cultivated in Egypt as a food protein supplement. Z. Ernahrungswiss, 15: 333-339.

24. Ginsberg, H.N. (1996): Diabetic dyslipidemia basic mechanisms underlying the common hypertriglyceridemia and low HDL Cholesterol levels. Diabtes., 45(3): 527-530.

25. Gray, A.M.; Abdel-Wahab, Y.H.A. and Flatt, P.R. (2000): The traditional plant tratment, Sambucus nigra (elder), exhibits insulin like and insulin releasing actions in vitro. J. of Nutr., 130: 15-20.

26. Gray, A.M. and Flatt, P.R. (1997): Pancreatic and extrapancreatic effects of the traditional anti-diabetic plant Medicago sativa (Lucerne). Br. J. Nutr., 78: 325-334.

27. Gray, A.M. and Flatt, P.R. (1998): Action of the traditional antidiabetic plant, agrimony (Agrimony eupatoria): effects on hyperglycaemia, cellular glucose metabolism and insulin secretion. Br. J. Nutr., 80: 109-114.

28. Harazti, E. and Vetter, J. (1983): Studies of factors influencing the nutritional value, palatability and toxicity of different lupine seeds. Acta. Agorn. Acid. Sci. Hung., 32(12): 23-29.

29. Hartnett, E.M.; Stratton, R.D.; Browne, R.W.; Rosner, B.A.; Lanham, R.J. and Armstrong, D. (2000): Serum Markers of oxidative stress and severity of diabetic retinopathy. Diabet. Care, 23: 234-240.

30. Helmi, R.; El-Mahdy, H. A.; Khayyal, M.A.H. (1969): Preliminary report on the hypoglycemic effect of Trifolium alexandrium and Lupinus termis in animal and man. J. Egypt. Med. Ass., 52: 538-551.

31. Jaiprakash, R.; Ran, M.A.; Venkataraman, B. V. and Andrade, C. (1993): Effect of felodipine on serum lipid profile in short term streptozotocindiabetes in rats. Indian. J. Exp. Biol., 31(3): 283-284.

32. Jung, U. J.; Lee, M-K; Jeong, K-S and Choi, M-S (2004): The hypoglycemic effects of hesperidin and naringin are partly mediated by hepatic glucoseregulating enzymes in C57BL/KsJ-db/db mice. J. Nutr., 134: 2499-2503.

33. Kesavulu, M.M.; Giri, R.; Kameswara, R.B. and Apparao, C. (2000): Lipid peroxidation and antioxidant enzyme 
levels in type 2 diabetic with microvascular complications. Diabet. Metabol., 26: 387-392.

34. Kimura, M.; Waki, L.; Chujo, T. ; Kikuchi, T.; Hiyama, C.; Yamazaki, K. and Tanaka, O. (1981): Effects of hypoglycemic components in Ginseng radix on blood insulin release from perfused rat pancreas. J. Pharm. Dyn., 4: 410-417.

35. Lemus, I.; Garcia, R. ; Delvillar, E. and Knop, G. (1999): Hypoglycemic activity of four plants used in popular medicine. Phytother. Res., 13(2): 91-94.

36. Lillioja, S.; Mott, D.; Howard, B. and Bogardus (1988): Impaired glucose tolerance as a disorde of insulin and crosssectional in pima Indians. N. Engl. J. Med., 318: 1217-1225.

37. Margolis, R.N.; Selawry, H.P. and Curnow,R.T.(1985): Regulation of hepatic glycogen metabolism: Effects of diabetes, insulin infusion and pancreatic islet transplantation. Metabolism, 34: 62-68.

38. Mohen, V.; Romachanran, A. and Viseranathan, M. (1991): Malnutrition Related Diabetes Mellitus. In William, G. ed. Text Book of Diabeted. Vol. I., Oxford, Blact, 247-255.

39. Montgomery, R.; Dryer, R. L.; Conway, T. W. and Spector, A.A. (1980): Regulation of the pentose phosphate pathway. In. Biochemistry, A case Oriented Approach, P. 308-310.

40. Mortimore, G. E. and Mondon, C. E. (1970): Inhibition by insulin of valine turnover in liver. J. Biol. Chem., 245: 2375-2383.

41. Murakami, K.; Kondo, T.; Ohtsuka, Y.; Fujiwara, Y.; Shimada, M. and Kawakami, Y. (1989): Impairment of glutathione metabolism in erythrocytes from patients with diabetes mellitus. Metabolism, 38: 753-758.

42. Nair, K.S.; Garrow, T.S.; Ford, C.; Mahler, R. F. and Halliday, D. (1983): Effect of poor diabetic control and obesity on whole protein metabolism in man. Diabetologia, 25: 400-403.

43. Niskikimi, M.; Rao, N. A. and Yagii K. (1972): The occurance of superoxide anion in the reaction of reduced phenazine methosulfate and molecular oxygen. Biochem. Biophys. Res. Comm.; 46: 849-854.

44. Orchard, T.J. (1990): Dyslipopro-teinemia and diabetes. Endocrinol. Metab. Clin. North. Am., 19: 361-379.

45. Ortmeyer, H.K.; Bodkin, N.L. and Hansen, B.C. (1994): Relationship of skeletal muscle glucose-6-phopsphate to glucose disposal rate and glycogen synthase activity in insulin resistant and non-insulin dependent diabetic Rhesues monkeys. Diabetologia, 37: 127-133.

46. Othman, AB.; Edress, G. M.F. and ElHamady, S. M. (1989): A possible role of soyabean in regulation of serum liver and urine minerals of alloxan diabetic rats. Bulletin of Egypt. Soc. Physiol. Sci., 9(5): 49-71.

47. Prins, H. K. and Loose, J. A. (1969): Glutathione " chapter 4" in Biochemical Methods in Red Cell Genetics. Edited by J.J. Yunis. Academic press, N.Y.D. London. PP.126-129.

48. Reddy, S. and King, G.L. (1987): Insulin Receptor on Uptake the Diabetes. Annual Vol. 3. Alberti, K.G.M.M. Kial L.P., Eds. Amsterdam, Elsevier, PP. 449-458.

49. Riyad, M.A.; Abdul-Salam, S. A. and Mohammad, S.S. (1988): Effect of fenugreek and lupine seeds on the development of experimental diabetes in rats. Planta Medica, 54(4): 286-290.

50. Rodriquez, M.M.; Guerrero, R.F. and Lazcano, B.G. (1998): Lipid and glucose lowering efficacy of Plantago psyllium in type II diabetes. Diabetes-complications, 12(5): 273-278.

51. Saudek, C. D. and Eder, H. A. (1979): Lipid metabolism in diabetes mellitus. Am. J. Med., 66: 843-852.

52. Scoppola, A. ; Montechi, F. R. ; Mezinger, G. and Lala, A. (2001) : Urinary mevalonate excretion rate in type 2 diabetes: Role of metabolic control. Atherosclerosis, 156: 357-361.

53. Shani, J. Goldschmied, A.; Joseph, B.; Ahronson, Z. and Sulman, F. G. (1974): Effects of Trigofnella foenum graecum and lupinus termis (Leguminosae) seeds and their major alkaloids in alloxan diabetic and normal rats. Arch. Intern. Pharmacodyn. Ther., 210: 27-37.

54. Sheela,C.G. and Augusti, K.T. (1992): Antidiabetic effects of S-ally I cysteine sulphoxide isolated from garlic Allium sativum. Indian S. Exp. Biol., 30(6): 523526.

55. Snedecor, G. W. and Cochran, W. G. (1982): Statistical Methods $7^{\text {th }}$ ed. The Stae University Press American, Iowa.

56. Sozmen, E.Y.; Sozmen, B.; Delen, Y. and Onat, T. (2001): Catalase/superoxide dismutase (SOD) and catalase / paraoxonase(PON) ratios may implicate poor glycemic control. Arch. Med. Res. 32: 283-287.

57. Trowell, H. C. (1972): Ischemic heart disease and dietary fiber. Am. J. Clin. Nutr., 25: 2926-932. 
58. Tsutsumi, K.; Inoue, Y.; Shime, A. and Murase, T. (1995): Correction of hypertriglyceridemia with low and high density lipoprotein cholesterol by the novel compound No. 1986, a lipoprotein lipase promoting agent in STZ-induced diabetic rats. Diabetes, 44:414-417.

59. Uchimura, K.; Nagasaka, A.; Hayashi, R.; Makino, M.; Nagata, M.; Kakizawa, H.; Kobayashi, T.; Fujiwara, K.; Kato, T.; Iwase, K.; Shinohara, R.; Kato, K. and Itoh, M. (1999): Changes in superoxide dismutase activities and concentrations and myeloperoxidase activities in leucocytes from patients with diabetes mellitus. J. Diabet. Complications, 13: 264-270.

60. Ugochukwu, N.H.; Babady, N.E.; Cobourne, M. and Gasset, S.R. (2003): The effect of Gongronema latifolium extracts on serum lipid profile and oxidative stress in hepatocytes of diabetic rats. J. Biosci., 28: 1-5.

61. Van-Handle, E. (1965): Estimation of glycogen in small amounts of tissue. Anal. Biochem., 11: 256-262.

62. Weber, G. F. (1994): The pathophysiology of reactive oxygen intermediates in the central nervous system. Medical Hypotheses., 43: 223-230.

63. White, J. R. and Campell, R. K. (1993): Magnesium and diabetes: A review. Ann. Pharmacother, 27: 775-780.

64. Wolff, P.; Jiang, Z. Y. and Shunt, J.V. (1991): Protein glycation and oxidative stress in diabetes mellitus and aging. Free Rad. Biol. Med., 10: 339-352.

65. Youness, R. I.; Ahmed, H.H.; Fayez, M.; Mansour, S.A. and Soliman, F. A. (1985): The hypoglycemic effects of some commonly used plants and seeds. Zool. Soc. Egypt. Bull., 35: 121-128.

66. Zaahkouk, S.A.M. (2001): Studies on the effect of some antdiabetic plants (Lupinus termis) and Trigonella foenum gracium) seeds extract on some physiological aspects of streptozotocin-diabetic rats. J. Union Arab. Biol. 16(A): 447-470.

67. Zahran, F. M. (2004): Therapeutic effect of diamicron or/and Lupinus termis on non-insulin dependent diabetes mellitus rats. J. Egypt Ger. Soc. Zool. 45(A): 569596. 


\section{تأثير بذور الترمس ومستخلصه المائي على الجرذان المصابة بمرض باض

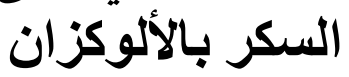

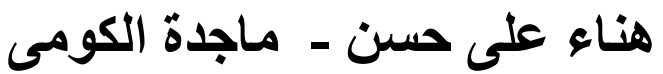

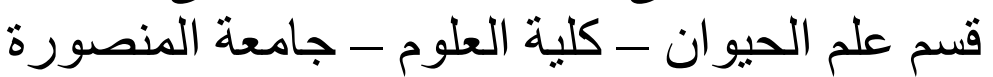

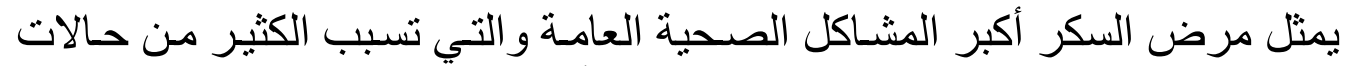

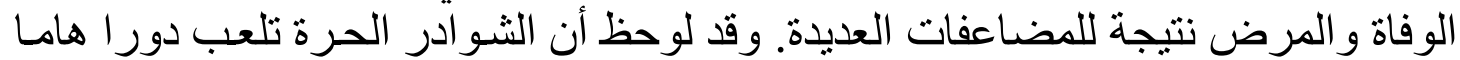

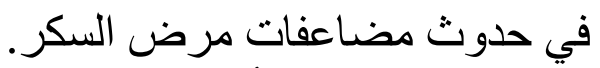

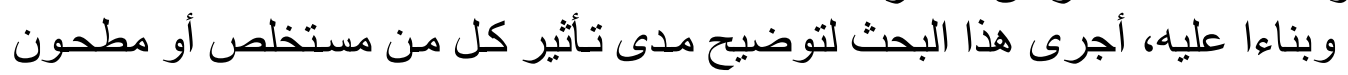

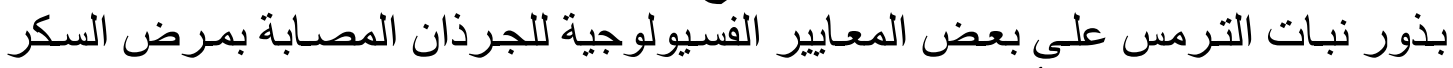

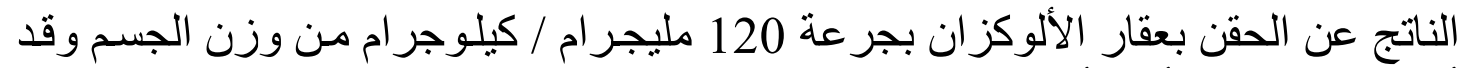

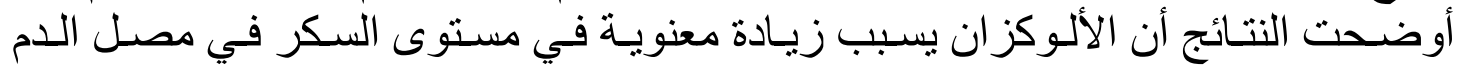

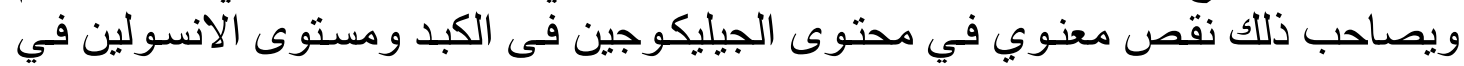

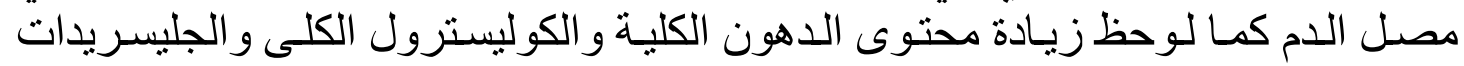

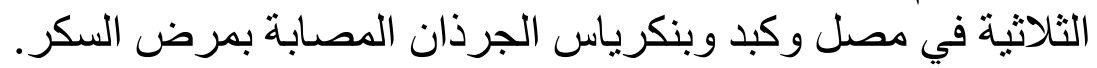

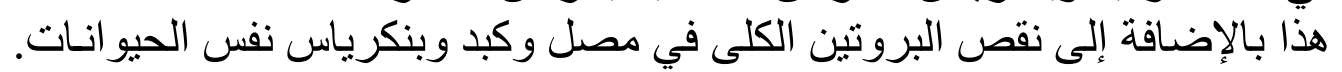

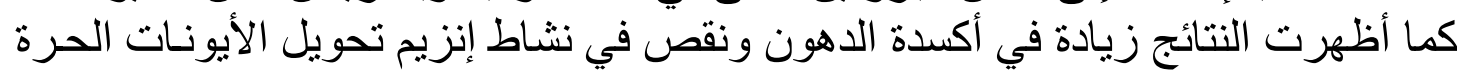

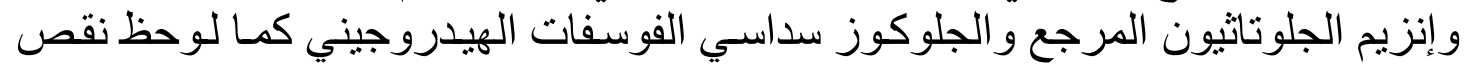

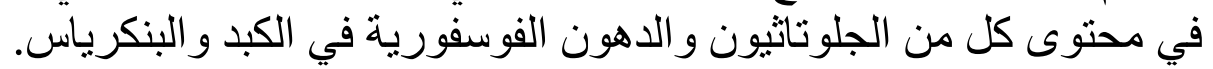

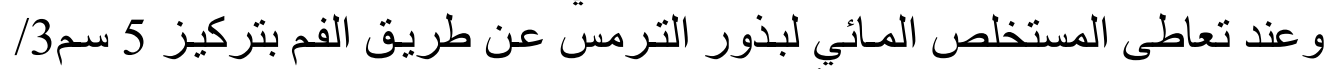

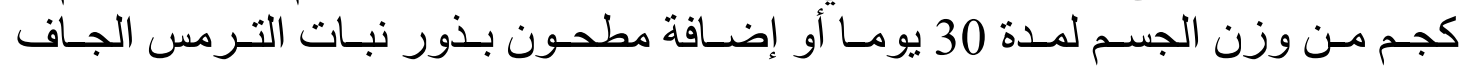

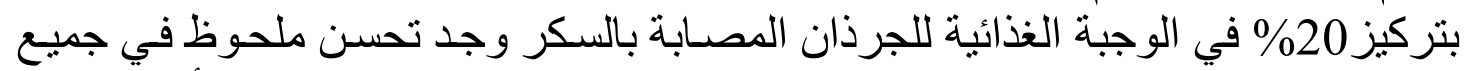

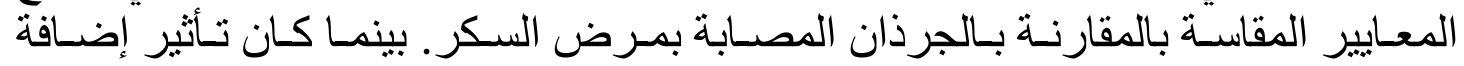

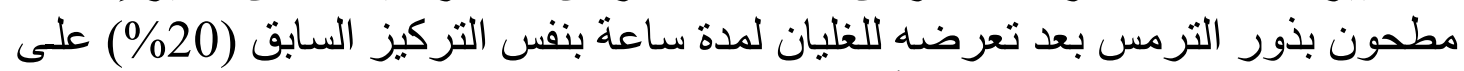

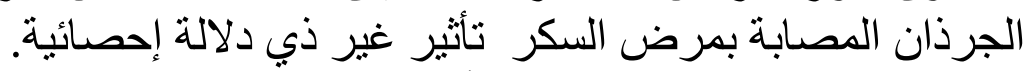

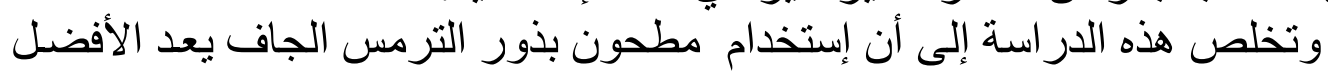

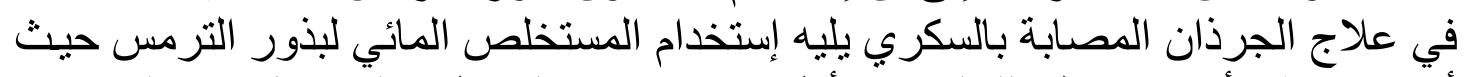

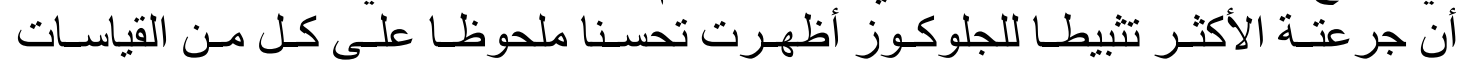

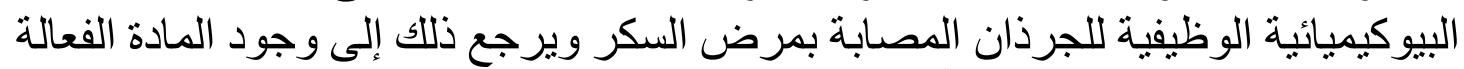

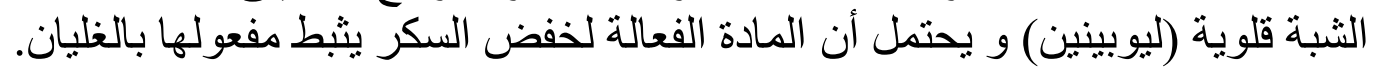

